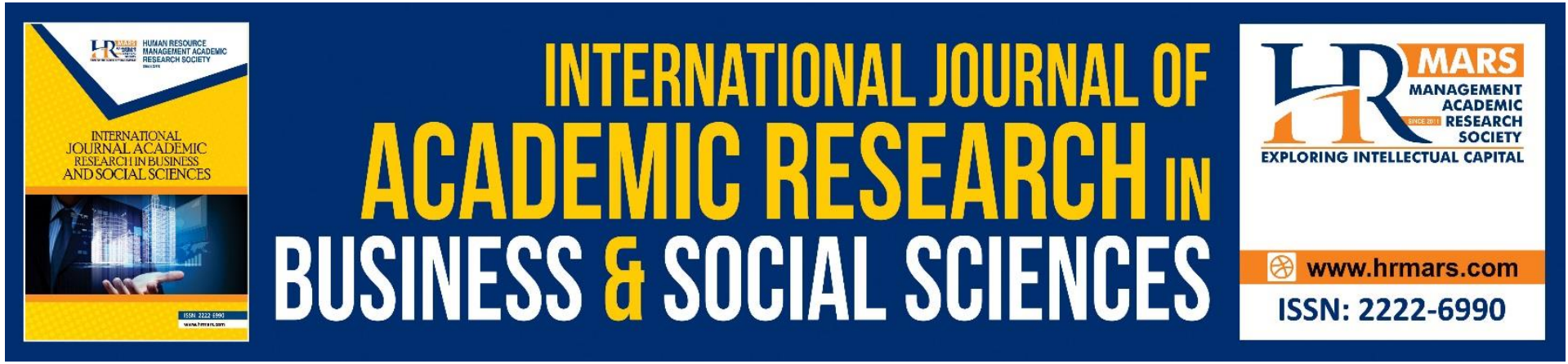

\title{
Speech Act Among Generation Y Students at Universiti Putra Malaysia
}

Muhammad Amirul Kamarudin, Zaitul Azma Zainon Hamzah, Nor Azuwan Yaakob

To Link this Article: http://dx.doi.org/10.6007/IJARBSS/v11-i7/10522

DOI:10.6007/IJARBSS/v11-i7/10522

Received: 10 May 2021, Revised: 20 June 2021, Accepted: 12 June 2021

Published Online: 27 July 2021

In-Text Citation: (Kamarudin et al., 2021)

To Cite this Article: Kamarudin, M. A., Hamzah, Z. A. Z., \& Yaakob, N. A. (2021). Speech Act Among Generation Y Students at Universiti Putra Malaysia. International Journal of Academic Research in Business and Social Sciences, 11(7), 645-654.

Copyright: @ 2021 The Author(s)

Published by Human Resource Management Academic Research Society (www.hrmars.com) This article is published under the Creative Commons Attribution (CC BY 4.0) license. Anyone may reproduce, distribute, translate and create derivative works of this article (for both commercial and non-commercial purposes), subject to full attribution to the original publication and authors. The full terms of this license may be seen at: http://creativecommons.org/licences/by/4.0/legalcode

Vol. 11, No. 7, 2021, Pg. 645 - 654

Full Terms \& Conditions of access and use can be found at http://hrmars.com/index.php/pages/detail/publication-ethics 


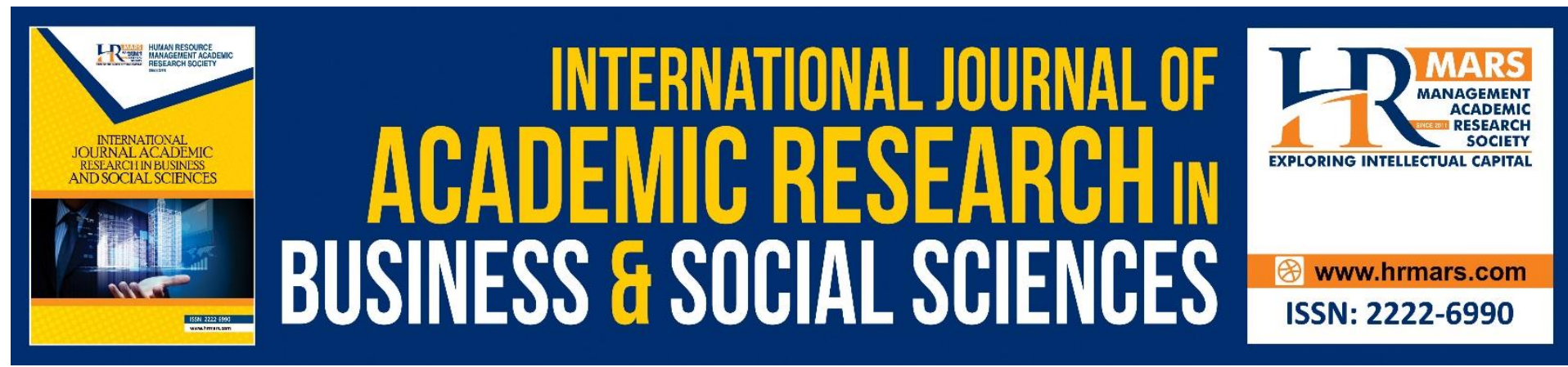

\title{
Speech Act Among Generation Y Students at Universiti Putra Malaysia
}

\section{Muhammad Amirul Kamarudin, Zaitul Azma Zainon Hamzah, Nor Azuwan Yaakob}

Faculty of Modern Languages and Communication, Universiti Putra Malaysia, 43400

Serdang, Selangor, Malaysia.

\begin{abstract}
Speech acts can be categorized as a forms of utterance which is have aspects of actions that have been produced by a language speaker. Typically, speech act exists in a communication situation that involves a conversation between two parties, that are the speaker and the listener. It can be said that every conversation that has been produced by a language speaker involves an aspect of speech act. Therefore, the conversational analysis has been chosen as the focus of the study to analyze aspects of speech act used by language speakers. Accordingly, this study was conducted to identify the aspects of speech act involved in the conversation of Generation Y students and analyze the use of aspects of speech act based on selected theories. In this study, the researcher has used the research method by making observations and voice recordings involving the conversations of Generation $Y$ students at Universiti Putra Malaysia (UPM). Furthermore, the selection of the sample study was done by using purposive sampling method and this study involved eight recordings of conversations. Each recording of the conversation was transcribed and each data of the study was analyzed qualitatively using the Speech Act Bach and Harnish Theory (1979). The categorization of Speech Act by Bach and Harnish (1979) consists of four act namely constatives, directives, commisives and acknowledgements speech act. However, in this study, the researcher only focused on the constative speech act only. The results of the study showed that each conversation data that was analyzed based on the eight recordings of the conversation involved aspects of the constative speech act. Therefore, this study shows that Generation $Y$ students also used the aspects of speech act in their daily conversations. Each speech act used by the Generation $Y$ students has a specific function or purpose.
\end{abstract}

Keywords: Speech Act, Conversation, University Student, Generation Y, Speech Act Bach and Harnish Theory

\section{Introduction}

Speech act can be seen through two way communication that involve two persons, namely the speaker and the listener. Speech act involves the aspects of actions or behaviors that can be seen through utterances that have been produced by a language speaker (Searle, 1969). The language can be categorized as an information exchange tool that is often used by a person when trying to convey a message to another person. In the verbal communication, 
speech act was plays an important role based on the type and function of speech act that has been used by speaker. This is because each utterance involved in a conversation has a different expression of its conduct i.e. whether to forbidding, make an agreement, informing, asking and so on. If the listener is unable to understand the purpose of the utterance delivered by the speaker, then the main goal of the conversation is not successfully used.

Moreover, speech acts also occur based on the force of utterance which acts as a speech acts which serves as an expression of an attitude of the speaker (Aman, 2011). In the meantime, the type of attitude expressed is in line with the type of utterance that was uttered by the language speakers. The success of a utterance can be determined by the listener himself whether the listener understands the intention or attitude of the utterance. For example, utterance such as "I'm sorry for not being able to complete the task that has been given". That utterance consists of the aspect of apologizing speech act. That utterance can show the attitude of the speaker who acts as an expression of regret for something that has happened. If the listener can forgive the speaker after hearing the apology, this shows that the listener understands the intention or attitude of the speaker based on the utterance that has been expressed. Through this study, the aspect of the use of speech act that involves the conversation of Generation Y students at Universiti Putra Malaysia (UPM) is the main focus of the study.

\section{Research Objective}

This study was conducted to identify the aspects of constatives speech act involved in the conversation of Generation $Y$ students and analyze the use of constatives speech act involved in the conversation of Generation Y students.

\section{Study Limitations}

This study focused on the verbal speech act that found in the conversations of Generation $Y$ students in local university. The group of students targeted by the researcher consists of individuals born in 1995 to 1997 in line with the group of Generation Y. In this study, the researcher has selected a total of 30 students of Universiti Putra Malaysia (UPM) as a sample study in conducting conversation recordings. The selection of the sample study was selected based on purposive sampling method without being limited by gender, religion and race. This study involved eight recordings of conversations and each of the conversation data will be used for the purpose to identifying aspects of speech act involved. Speech Act Bach and Harnish Theory (1979) consists of four acts namely the constatives, directives, commisives and acknowledgements speech act. However, in this study, the researcher only focused on one speech act only, that is constatives speech act. The researcher will identify the constatives speech act involved in each conversation that has been conducted and analyze the data based on selected theories. Thus, this study will be able to identify the constatives speech act involved in the conversation of Generation Y students at UPM.

\section{Literature Review}

Ahmad, Ahmad and Shaharuddin (2020) was conducted a study of speech acts that is involving requesting act among Malay students. The aim of this study was to researching the use of requesting act among Malay students based on the context of the situation in a particular social domain. A total of 20 students of UiTM Shah Alam consisting of students of the Academy of Language Studies were selected as study respondents. Researchers have used 
the Discourse Completion Task Method based on 10 situational contexts in an effort to collect data. Three aspects of the context of the situation were constructed in the form, namely social relations, communication medium and conversational background. In the meantime, researchers have used the request categories presented by Blum Kulka, House and Kasper (1989) as well as request strategies presented by Hassal (2003) and politeness principle Asmah's (2000) in an effort to analyze data related to request act. The researcher has concluded that the UiTM students have applied the use of a clear sequence of requests according to the context of a particular situation and domain while delivering the act.

Next, Shuib and Yusof (2019), also conducted a study of speech act involving the aspects of religious talks. This study was conducted with the aim of researching the types of speech act commonly used by speakers in religious talks conducted by them. In this study, the researcher has selected a religious talk that consists of talks delivered by Ustaz Azhar Idrus and Ustazah Siti Nor Bahyah Mahmood. Researchers have used Searle's Speech Act Theory (1969) in the process of analyzing the types of speech act involved in such religious talks. The results of this study show that each content of the religious talk involves certain aspects of speech act and among the speech act involved consists of assertive, directive, expressive and commissive speech act. Through this study, researchers have concluded that speech act is part of the barrel of religious talks that can contribute to the effectiveness in the delivery of talks conducted.

Furthermore, a study of speech act involving the aspects of Friday sermon text was conducted by Laengkang (2018). The researcher has conducted a study with the aim to identifying the speech act involved in the text of the Friday sermon that has been published by the Selangor Islamic Religious Department. In this study, the researcher has used six texts of Friday sermons read in 2018 namely two texts in February, two texts in March and two texts in April. Each text of the Friday sermon was analyzed using the theoretical framework of speech act by Bach and Harnish (1979). The researcher has concluded that there are three categories of act and 13 subcategories of act have been identified namely advising speech act, descriptive speech act and assertive speech act. This study shows that Friday sermons are more descriptive and advising.

The study of speech act also involved two way conversation or communication. However, the study conducted consists of aspects of language use that are different from this study that involves spontaneous conversation without having a specific topic of conversation. The study conducted by Mohamad and Hamzah (2018) involves speech act in flood events and this research objective are to analyze and summarize the types of speech act related to flood events that have been used by the community in Kelantan. Researchers have used interview, recording and observation methods in the process of examining video transcripts. This study involved five videos and the researcher analyzed the data contained in each video based on the Theory of Speech Act by Searle (1969). The results of this study found that there were various acts that existed in the conversation of the flood event. For example, there are declarative, expressive, representative, directive and commissive speech act. Each of these speech acts has a specific language function.

Juhari and Hamzah (2015) also conducted a study of speech act that involves two way communication that consists of management meetings. The speech act aspect was involves 
in formal communication i.e. discussion or sharing on management matters. This study was conducted with the objective to identifying the types of speech act that is used in meeting situations. The researcher used the field study method and observations with recording the meeting by using audio recorder. A total of five meeting sessions were recorded and each recording was transcribed for the purpose to analyzing the speech act involved in each meeting session. In this study, the researcher has used the Theory of Speech Act by Searle (1969) and the Categorization of Speech Act by Bach and Harnish (1979) while analyzing the speech act data involved. The data of the study were analyzed and explained qualitatively. Researchers have concluded that the most dominant speech act in that meetings is directive acts. This is in accordance with the principle of the meeting that each discussion directs or asks for feedback from someone as a listener for example in terms of questioning.

\section{Methodology}

This study was conducted using a qualitative approach by involving a field study consisting of Generation Y students of local university. In this study, Generation Y students at Universiti Putra Malaysia born in 1995 to 1997 were selected as the sample study. A total of 30 students were selected based on purposive sampling without being limited by gender, race and religion to help this study be conducted. The researcher has chosen the area around the Serumpun College Cafeteria at UPM as the place to conduct the study. A total of eight conversation recordings were involved in this study and each recording was transcribed for the purpose of identifying the data involved.

Next, these data will be analyzed based on Speech Act Bach and Harnish Theory (1979). This theory involves four types of speech act, namely the constatives, directives, commisives and acknowledgments speech act. However, in this study, the researcher only focus to study the data which consisted of constatives speech act only. The researcher will identify the constatives speech act found in each conversation that has been recorded and each data involving the use of the constatives speech act will be analyzed based on the use of relevant subcategories. This is because each utterance that has been spoken by the sample study has a specific purpose based on the context of the conversational situation.

\section{Analysis and Discussion}

This section shows that there are some research data involving the constatives speech act has been used by Generation Y students at UPM. The data of the study will be analyzed based on the selected research theory, namely the Speech Act Bach and Harnish Theory (1979). 
Table 1. List of Constatives Speech Act involved in Conversation of Generation Y Students at Universiti Putra Malaysia

\begin{tabular}{|c|c|c|}
\hline No. & Utterance & Conversation \\
\hline 1. & $\begin{array}{l}\text { Macam aku, aku pergi dia punya pejabat ambil form. Lepas tu } \\
\text { isi form tu, aku bagi balik. Lepas tu, kelmarin ka aku cerita } \\
\text { dapat mesej. }\end{array}$ & $\begin{array}{l}\text { Conversation } \\
1\end{array}$ \\
\hline 2. & $\begin{array}{l}\text { Dia macam kalau dah disahkan then kau akan dapat. Tapi } \\
\text { kalau dia tak hantar tu maksudnya permohonan tu macam } \\
\text { tak sampai ke sana la. }\end{array}$ & $\begin{array}{l}\text { Conversation } \\
1\end{array}$ \\
\hline 3. & $\begin{array}{l}\text { Aku ni kalau rajin pandai saja tapi sebab aku ni pemalas. } \\
\text { Malas aku ni teruk sangat. }\end{array}$ & $\begin{array}{l}\text { Conversation } \\
2\end{array}$ \\
\hline 4. & $\begin{array}{l}\text { Takut boleh jadi sampai pukul } 5 \text {. Sebab ada presentation kan } \\
\text { dan biasanya presentation kelas ganti. }\end{array}$ & $\begin{array}{l}\text { Conversation } \\
2\end{array}$ \\
\hline 5. & $\begin{array}{l}\text { Aku cari stokin aku, tak ada. Warna hitam, tak tahu ke mana. } \\
\text { Lepas tu aku pakai stokin yang warna ni, berjari pula tu. }\end{array}$ & $\begin{array}{l}\text { Conversation } \\
3 \\
\end{array}$ \\
\hline 6. & $\begin{array}{l}\text { Sebab tu aku kata lepak saja sini. Kalau bilik, ganggu } \\
\text { roommate. Aku malas la, roommate aku tadi pun tengah on } \\
\text { call. }\end{array}$ & $\begin{array}{l}\text { Conversation } \\
3\end{array}$ \\
\hline 7. & $\begin{array}{l}\text { Nanti kita boleh cari macam mana dia boleh dapat ilham nak } \\
\text { jadi penulis. Dia punya jatuh bangun dia. }\end{array}$ & $\begin{array}{l}\text { Conversation } \\
4\end{array}$ \\
\hline 8. & $\begin{array}{l}\text { Kalau untuk last page, mungkin kita boleh masukkan dia } \\
\text { punya mutiara kata kot. }\end{array}$ & $\begin{array}{l}\text { Conversation } \\
4\end{array}$ \\
\hline 9. & $\begin{array}{l}\text { Tapi sebenarnya budak-budak FBMK kan ramai yang even dia } \\
\text { orang Malay pun dia orang cakap bahasa Inggeris. }\end{array}$ & $\begin{array}{l}\text { Conversation } \\
5\end{array}$ \\
\hline 10. & $\begin{array}{l}\text { Dia orang macam pandang rendah juga la dekat orang yang } \\
\text { berbahasa Melayu ni. }\end{array}$ & $\begin{array}{l}\text { Conversation } \\
5\end{array}$ \\
\hline 11. & Senior pun cakap, course ni memang susah nak skor. & $\begin{array}{l}\text { Conversation } \\
6\end{array}$ \\
\hline 12. & $\begin{array}{l}\text { Saya nampak dia, saya nak tegur dia. Tapi dia macam tak } \\
\text { ingat saya. Saya pun buat tak nampak dia, saya lalu saja. }\end{array}$ & $\begin{array}{l}\text { Conversation } \\
6 \\
\end{array}$ \\
\hline 13. & Week 13, week 14 tiada kelas dia kata. & $\begin{array}{l}\text { Conversation } \\
7\end{array}$ \\
\hline 14. & Dia balik masjid, dia terus datang sini la. & $\begin{array}{l}\text { Conversation } \\
7\end{array}$ \\
\hline 15. & Tapi kan memang boleh nampak lelaki lambat matang. & $\begin{array}{l}\text { Conversation } \\
8\end{array}$ \\
\hline 16. & $\begin{array}{l}\text { Tak ada sebab kita orang duduk kampung. So memang kucing } \\
\text { tu berlambak sangat. Memang tak akan ada orang nak punya. }\end{array}$ & $\begin{array}{l}\text { Conversation } \\
8\end{array}$ \\
\hline
\end{tabular}

Table 1 above has shown that there are 16 utterances involving the constatives speech act. Each utterance has its own message or purpose based on the context of the conversation situation. The effectiveness the use of the constatives speech act can be obtained when both the speaker and the listener can understand each utterance that has been produced by them. 


\section{The Analysis of Constatives Speech Act by Generation Y Students at UPM}

Table 1 has shown that there are utterances that have been produced by Generation $Y$ students consisting of constatives speech act. Some of the data will be analyzed based on Speech Act Bach and Harnish Theory (1979).

Constatives speech act can be categorized as the act that involve aspects of the speaker's wishes or intentions, beliefs as well as knowledge so that the listener has the same knowledge or understanding of each message that has been conveyed by the speaker (Bach \& Harnish, 1979).

P: Tak ada apa-apa pun. Ke dia kena check dekat website?

P: Macam aku, aku pergi dia punya pejabat ambil form. Lepas tu isi form tu, aku bagi balik. Lepas tu, kelmarin ka aku cerita dapat mesej.

P: Dua hari ke tiga hari lepas.

(Source: Conversation 1)

The utterance above that is "Macam aku, aku pergi dia punya pejabat ambil form. Lepas tu isi form tu, aku bagi balik. Lepas tu, kelmarin ka aku cerita dapat mesej" can be categorized as an constatives speech act. In the utterance, the speaker has produced a utterance that involves a subcategory of descriptive act that is by describing the framework of something. The speaker explained something to the listener about the process of applying for educational assistance that she had done from the initial stage until the application was successful. The utterance that has been produced by the speaker is intended to give an idea or knowledge to the listener about the same thing. The listener can do something based on what has been said by the speaker, that is, she can get the application form at the office and fill in the form, then return the completed form. In this case, utterances that involve descriptive actions have a role in the actions that a person can take based on the context of the utterance's needs. This coincides with the opinion of Aziz (2011) who has stated that the utterance produced by a person has the purpose to create an action or behavior. Thus, based on the Speech Act Bach and Harnish Theory (1979) clearly show that the data of this study are related to descriptive speech act.

P: Kafe ni sampai pukul berapa?

P: Kafe ni sampai pukul 10 saja.

P: Tak, maksud aku lampu-lampu ni.

P: 12, ada sebelah sana tu tutup, sebelah sini buka. Sebab tu aku kata lepak saja sini. Kalau bilik, ganggu roommate. Aku malas la, roommate aku tadi pun tengah on call.

(Source: Conversation 3)

The utterances found in that conversation have the constatives act that was to informing something to someone else. That information include to something that have happened, is happening or will happen according to the context of the conversation situation. In the utterance of this conversation, the subcategory act of informing about somethings that have not yet happened has been uttered by the speaker. That can be seen by utterance "Sebab tu aku kata lepak saja sini. Kalau bilik, ganggu roommate. Aku malas la, roommate aku tadi pun tengah on call". In the context of this conversational situation, the speaker had made an 
inform about a situation where she did not want to disturb the privacy of her roommate if her friends were gathered in the room. Therefore, the decision to gather at the cafeteria can be said to be one of the good decisions that can build the satisfaction of all parties. In this case, the listener needs to respond or accept the utterances they have heard in order to establish an effective communication. The listener needs to understand the reason or purpose of the utterance that has been produced by the speaker. This can be supported through the view of Aziz (2011) that every expression of the conversation has been taught serves as a trigger for an action. Thus, based on the Speech Act Bach and Barnish Theory (1979) clearly show that the data of this study are related to informing speech act.

P: Ada siapa lagi dengan you?

P: Ada kawan baik saya, Fatin. Najmuddin kenal?

P: Oh Naj. Saya nampak dia, saya nak tegur. Tapi dia macam tak ingat saya. Saya pun buat tak nampak dia. Saya lalu saja.

(Source: Conversation 6)

The speaker in this conversation has created a speech act in terms of stating by making the utterance "Saya nampak dia, saya nak tegur. Tapi dia macam tak ingat saya. Saya pun buat tak nampak dia. Saya lalu saja." to the listener of the conversation. In the context of this conversational situation, the speaker has made a statement by using the phrase 'saya nampak dia, saya nak tegur' which can mean stating something that has happened. The speaker has also made a statement about someone who does not remember herself and she has also decided to ignore about that person. In the context of this situation, the speaker wants to tell the listener about somethings that involve others so that the listener will gets the information about it. The information that has been shared by the speaker has their own purpose and the speaker want to build good communication between them. Omar (1997) argues that the act of statement can involve the action of stating an event, situation or anything to someone else. Besides, the speaker has used the act of statement while communicating with the listener. Thus, based on the Speech Act Bach and Harnish Theory (1979) clearly show that the data of this study are related to stating speech act.

P: Ala kesiannya. Kami pernah buang kucing.

P: Lepas tu, aku tak suka kalau buang kucing time aku ada dekat rumah. Sebab aku cakap, tunggu aku tak ada baru buang kucing tu.

P: Sebab takut rasa bersalah kan.

P: Selalunya kami saja selalu kena buang kucing dengan ayah kami. Sebab

mak

kami dan adik kami tak sampai hati.

P: Tak sampai hati even kita tak suka dia tapi sebab dia dah ada dekat kita.

P: Tak ada ke rasa nak viralkan ke apa ke?

P: Tak ada sebab kita orang duduk kampung. So memang kucing tu berlambak sangat. Memang tak akan ada orang nak punya.

(Source: Conversation 8)

Based on the utterances that have been uttered by the speakers that is "Tak ada sebab kita orang duduk kampung. So memang kucing tu berlambak sangat. Memang tak akan ada orang nak punya." and the researchers have found that the speakers have used responding speech act when communicating with the listener. The speaker has given a response or feedback quickly when listening to the previous utterance that is the question which has been uttered 
by the previous speaker that is "Tak ada ke rasa nak viralkan ke apa ke?". That responding by the speaker can answer the questions that have been presented by the questioner and that response given can make the listener feel so satisfied too. This conversational involves about cat related situation. The speaker has said that the dumping of cats around her village area makes no one interested in taking the cat as a pet. In the context of conversational situations, utterances that answer the questions can create an effective communication. Besides, the speaker has used the act of responding while communicating with the listener. Thus, based on the Speech Act Bach and Harnish Theory (1979) clearly show that the data of this study are related to responding speech act.

\section{Conclusion}

In conclusion, this study can prove that each utterance found in the eight recordings of conversations that have been produced by Generation $Y$ students at UPM consists of the constatives speech act. Through the Speech Act Bach and HarnisH Theory (1979), each constatives speech act has its own function or subcategory based on the context of the conversational situation that has been conducted. Among the subcategories involved in the conversation of the sample study consisted of descriptive, informing, stating and responding speech act. Generation Y students at UPM was used the speech act based on the main purpose of the conversation that they want to convey to the listener. The effectiveness of each utterance can be determined through the response from the listener after hearing the utterance that has been uttered by the speaker.

\section{Corresponding Author}

Muhammad Amirul Kamarudin

Malay Languange Department, Faculty of Modern Languange and Communication, Universiti Putra Malaysia, 43400 Serdang, Selangor, Malaysia.

Email: amirulkamarudin.edu593@gmail.com

\section{References}

Ahmad, N., Ahmad, A., \& Shaharuddin, G. S. (2020). Lakuan Bahasa Permintaan dalam Kalangan Pelajar Melayu di Akademi Pengajian Bahasa di UiTM Shah Alam. Jurnal Linguistik, 24(2), 1-26.

Aman, I. (2011). Mengurus Wacana dan Kepimpinan: Analisis Ucapan Sulung Perdana Menteri Baharu Malaysia. Jurnal Bahasa, 11(2), 235-272.

Aziz, S. H. A. (2011). Bahasa Melayu I Edisi Kedua. Malaysia, Selangor Darul Ehsan: Oxford Pelajar Sdn. Bhd.

Bach, K., \& Harnish, R. M. (1979). Linguistic Communication and Speech Acts. Cambridge \& London: The MIIT Press.

Juhari, A., \& Hamzah, Z. A. Z. (2015). Penggunaan Lakuan Pertuturan dalam Mesyuarat. Jurnal Linguistik, 19(1), 048-052.

Laengkang, A. G. (2018). Analisis Lakuan Bahasa Terhadap Teks Khutbah Jumaat Negeri Selangor. Jurnal Hal Ehwal Islam dan Warisan Selangor, 2(1), 1-18.

Mohamad, A., \& Hamzah, Z. A. Z. (2018). Struktur Bahasa dalam Situasi Banjir di Kelantan dari Sudut Lakuan Pertuturan. Journal of Social Sciences and Humanities, 3(3), 17-25.

Omar, A. H. (1997). Wacana Temuduga dan Wawancara. Malaysia, Kuala Lumpur: Dewan Bahasa dan Pustaka. 
INTERNATIONAL JOURNAL OF ACADEMIC RESEARCH IN BUSINESS AND SOCIAL SCIENCES

Vol. 11, No. 7, 2021, E-ISSN: 2222-6990 @ 2021 HRMARS

Searle, J. R. (1969). Speech Acts an Essay in The Philosophy of Language. London: Cambridge University Press.

Shuib, N. S., \& Yusof, M. (2019). Lakuan Bahasa dalam Ceramah Agama. Jurnal Akademika, 89(1), 41-53. 